\title{
Interactive monitoring and assessment of knowledge based on an adaptive learning system
}

\author{
JEL: 034 DOI: 10.24136/atest.2018.548 \\ Data zgłoszenia: 19.11.2018 Data akceptacji: 15.12.2018
}

The article deals with the problems, disadvantages and advantages of using adaptive learning systems in interactive monitoring and assessment of knowledge. Methodical and technical aspects of interactive monitoring and assessment of knowledge based on the adaptive learning system are defined. The schemes of the algorithms based on which the learning process with simultaneous interactive monitoring and assessment of knowledge is realized is offered. Recommendations on the use of software products for the implementation of interactive monitoring and assessment of knowledge based on an adaptive learning system are proposed.

Keywords: IT system, interactive monitoring, assessment of knowledge, adaptive learning, management.

\section{Introduction}

An important role in the organization of the educational process is to create conditions for students to work independently on the studied subjects using IT system and e-technologies [3]. An effective tool for interactive training are adaptive learning systems (ALSs), which provide educational material considering the level of training and abilities of each student. The ALSs manage the student's interactive learning process, consistently providing the learning material and evaluating the effectiveness of training, adjusting the course of the learning considering the individual abilities of the student $[1,2]$. It is obvious that the training involves continuous monitoring and assessment of the students' knowledge throughout the stage of interactive learning. Therefore, the ALSs introduces interrelated blocks of theoretical and practical study material in the form of coarse-grained units of knowledge, which we call topics, with the monitoring and assessment of students' knowledge [5, 14 and 16]. The monitoring and assessment of knowledge in adaptive learning is based on testing. This approach to adaptive learning allows students to work with self-assessment issues [2, 14] and continuously assess the risks associated with incorrect assessment of knowledge that meets the requirements of the ISO 9000 quality standard [13].

The ALS provides an operational and tactical management of the learning process in automatic mode [1].

The operational management of the learning process determines the order and conditions for the passage of the stages of interactive learning. For example, based on the results of the tests, the level of mastering the material of the studied discipline is determined. The current monitoring of knowledge and a positive assessment for each topic under study allows the student to proceed to the next stage according to the learning algorithm. In case a student has failed to cope with the proposed test tasks, he re-passes the training stage before receiving a positive assessment. At the last stage of interactive learning the final assessment of the student's level of knowledge is revealed.

The tactical management of the learning process is associated with adaptation to the level and abilities of each student. For exam- ple, in the process of interactive learning, taking into account the current diagnosis of the student's knowledge, adjustments are introduced into the order and level of the tasks provided, the composition and content of educational materials, the need for consultations with the teacher is established, the causes of failures in the learning process are identified, etc., the accumulation of the test items for database, a program of actions of the system developers aimed at improving the educational material, test tasks and the algorithm of adaptive learning is formed.

\section{Analysis of the functioning of existing adaptive learning systems}

Interactive learning is carried out using the ALSs, to which personal access of students and teachers is organized through the servers of the higher school and Internet technology. The ALSs contain both training materials and tools for diagnosing and assessment of the knowledge level on the topics of the studied discipline, database of test items, their solutions at various levels, including reference solutions. The number of test items should cover the entire training material of the studied discipline and provide for a given accuracy and reliability of the statistical assessment of knowledge [11]. In the papers [5, 12 and 17], The ALS was proposed, a feature of which is that the entire training material is divided into topics with three levels of the test items complexity. The first, second and third levels of the test items complexity correspond to the assessments of "excellent", "good" and "satisfactory". Each test includes from 5 to 10 text or graphic items. The ALS offers the student first item of the first level of complexity (corresponds to the "excellent" assessment). If he copes with this item, he moves on to the next element of the topic. If the student does not cope with the item of the first level, he moves to the second and, if necessary, further to the third level. The ALS can identify the learning process as stable or unstable, to identify progress or regression in the learning process, which allows to assess the effectiveness of student learning and, if necessary, to make timely adjustments to the course of interactive learning [4].

In the process of interactive learning, diagnostics and assessment of the level of knowledge are carried out, respectively, at the stages of current monitoring of knowledge and intermediate monitoring of knowledge, as a rule, after studying two or more topics of the discipline. With the current monitoring of knowledge, it is possible to move from the third level of items to the second and (or) to the first level, that is, the student can improve his of knowledge assessment. Features of the intermediate knowledge monitoring of knowledge are the presence of time limitations on the fulfillment of the items at each level, the prohibition on the use of any information sources, as well as the fact that the student is not given the right to improve his assessment by re-performing the items.

The intermediate monitoring differs from the current monitoring of knowledge by a smaller number of tasks (respectively at each level of complexity 10, 7, 7 and 5, 10,5), which are generated arbitrarily from the number of all variants of tasks used in the process of studying the subjects of the discipline [5]. The ALS informs the student of his / her current and final level of knowledge as he / she 
performs the proposed tasks, as well as allows the teacher to get acquainted with the results of diagnostics and assessments of the student's knowledge level during interactive learning and make personal adjustments to the training process.

The assessment of a student's knowledge in interactive training is carried out in a comprehensive manner, considering the average guaranteed ratings, obtained at two stages of current and intermediate knowledge monitoring. The significance of assessments of the two stages of monitoring in calculating the comprehensive assessment of knowledge is established by weighting factors. In a simplified approach, the weights are equal and correspond to 0.5. [12].

The disadvantage of such an ALS is that it requires preliminary theoretical training on the topic under study, as well as the similar system does not activate the cognitive component of the process of interactive learning. At this stage of monitoring, The ALS generates five unrelated test items to which the student must respond. With one wrong answer, the student moves from the first level to the second and gets ten new test items. With a positive result at the second level, the student returns to the first level and gets a new five test items on the topic under study. With a negative result on the second level of test items, the student moves to the third level with five test items. If the student copes with the test item of the third level, he / she moves to the second level. If you solve the task at the third level is not possible, it goes to the study of theoretical material and then returns to the first level of tasks and diagnostics of knowledge is repeated. Moreover, test tasks at different levels are not repeated and are not logically related to each other, although they belong to the same studied topic $[5,17]$. In fact, the current monitoring of the student's knowledge does not allow him to quickly diagnose gaps in knowledge, does not focus on the most important issues of the topic under study. Similar problems occur in the intermediate monitoring and assessment of the knowledge level of the student. Since mastering the subjects of higher school causes certain difficulties due to the different levels of initial training of students and their individual abilities, the improvement of interactive monitoring and assessment of knowledge in adaptive learning is an important task.

The aim of this paper is to improve the algorithm of interactive monitoring and assessment criteria of students' knowledge in the process of adaptive learning.

\section{Interactive monitoring and assessment of knowledge based on adaptive learning system}

With the advent of electronic technology, teachers have new opportunities for organizing interactive student learning and student knowledge management [15]. There are opportunities to use ALSs for interactive work of students, simplified procedures for monitoring and evaluating students' knowledge. The effectiveness of adaptive learning is increased using multimedia, innovative material for tanning, the development of adaptive algorithms for providing of material for tanning, the using of simple criteria for diagnosing and assessment of students' knowledge, making timely management decisions based on information about the learning process, the organization of information relations with the student, etc. [11] Along with these advantages, the disadvantages of the existing algorithms and criteria for knowledge assessment in adaptive learning are identified, which are included:

- monitoring of knowledge is carried out periodically after learning a part of the topic under study, which does not allow to timely identify gaps in knowledge of the student and to adjust the process of interactive learning;

- the clear majority of ALS is based on the closed form of test items with the choice of the correct answer from several pro- posed options, which does not allow to consider incomplete or partially correct answers and to establish the exact level of knowledge of the student being tested;

- the ALSs generate test items from the database without a logical connection with previous answers or without regard to their use in a previous item of test;

- test results with incomplete or partially correct answers are stored in the database without their use in assessing the knowledge of subsequent students;

- knowledge assessment is performed after all the test items are completed without considering their level of complexity.

There are many algorithms for choosing the order of test items. The choice of an algorithm depends on the purpose and the proposed of test scenario [6]. The purpose and scenario of testing determine the organization of interactive training, the supply of training material and methodological support, a set of test items of three levels of complexity, a description of the algorithm of their solutions, the condition for the end of testing, a database of reference solutions and incomplete and partially correct answers, specifying system information, recording results in the database, etc. The scenario and algorithm of testing should contribute to the achievement of a high level of training of the student with his high motivation.

To eliminate these shortcomings and implement a high-resultmotivated test scenario, algorithms for the current monitoring (Figure 1) and intermediate monitoring (Figure 2) of knowledge with an indication of the number of the test items and its level of complexity is proposed.

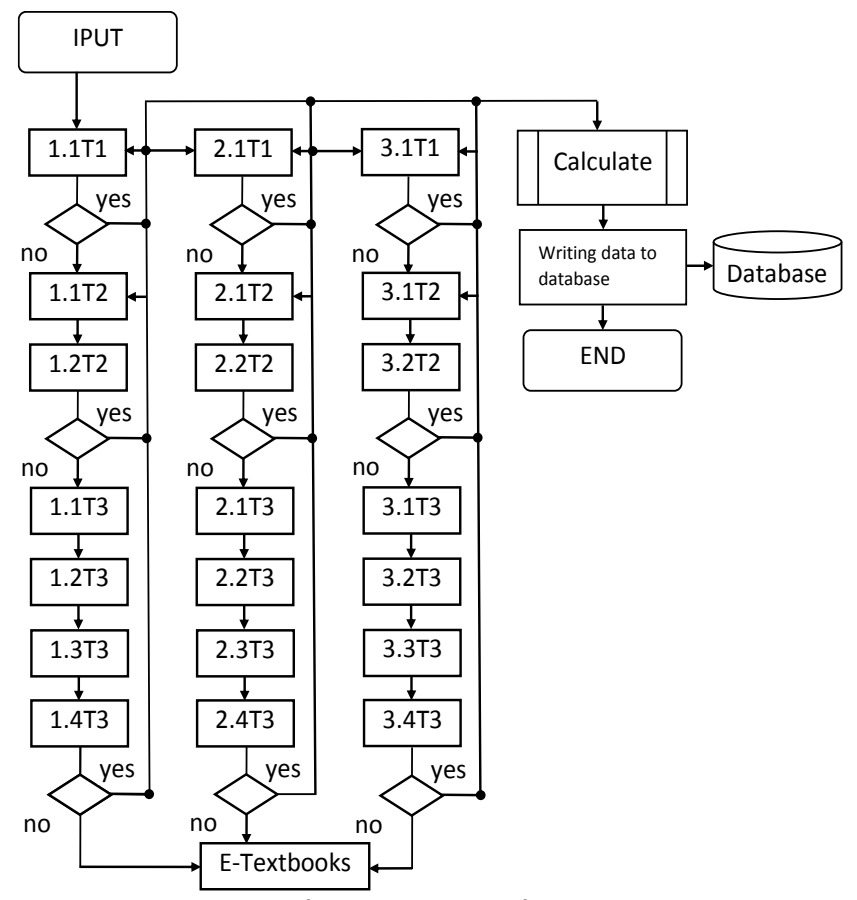

Fig. 1. The scheme of the algorithm for interactive diagnosing knowledge in adaptive learning

For example, the code designation $3.2 \mathrm{~T} 2$ of the test item means the following: the first digit is the number of the test item (3rd test item), the second digit is the number of the test item of the appropriate level of complexity (the 2nd test item of the second level of complexity, the third letter designation the type of the test item ( $T$ text item), the fourth digit - the level of complexity of test item (2nd level of complexity of test item).

Knowledge diagnostics is performed without increasing the total number of test items and time for its execution. The implementation 
of the algorithm for diagnosing knowledge does not require initial training in the discipline under study. A student can start interactive learning without waiting for relevant lectures in high school. There is also an option in which the student before starting to study received some knowledge on the topic under study in the lectures at the higher school. The student starts the training immediately with the diagnosis of knowledge. Knowing about the cyclical nature of this type of monitoring and the possibility to return to its beginning, the student is not afraid to get a low assessment. He / she confident that consistent work to address the identified knowledge gaps will eventually lead to high assessments in the two stages of knowledge monitoring.

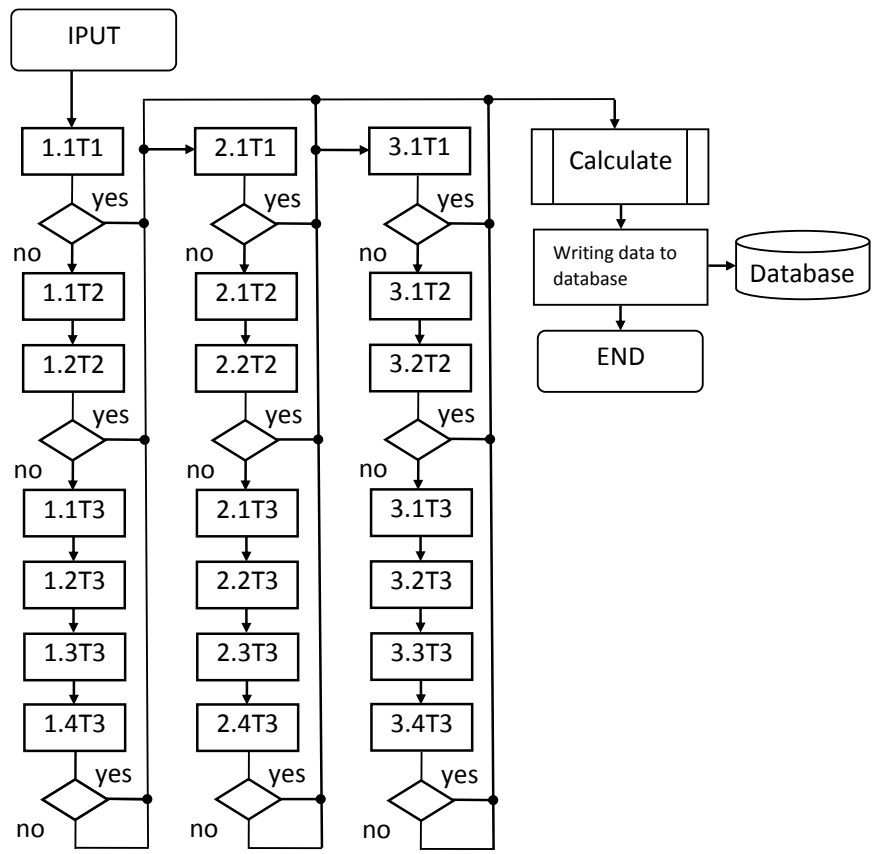

Fig. 2. The scheme of the algorithm for interactive assessment of knowledge level in adaptive learning

Knowledge diagnostics begins with providing the first test item of the highest level of complexity. The test item can be executed true with the assessment "excellent"(corresponds to the reference decision), correctly (incomplete decision with an assessment "good"), partially correctly (with an assessment "satisfactory"), incorrectly (with an assessment "unsatisfactory"). If the received positive assessment satisfies the student, he/she moves to the second test item of the first level of complexity and then the monitoring procedure is repeated. The total number of test items of the first level is within 3-4, depending on the complexity of the topic udder study. If the first test item of the highest level of complexity is incorrectly solved, the student gets two test items of the second level of complexity, which are consistently solved. A feature of the test items of the second level is that they are a decomposition of the first item, that is, they are subtasks of the previous test. In the case of solving the items of the second level with an assessment satisfying the student, he / she can proceed to the second test item of the first level of complexity and then to the subsequent test items.

If the test items of the second level of complexity are incorrectly solved, the student proceeds to the execution of four test items of the third level of complexity, which are consistently decided. The peculiarity of the test items of the third level is that they are a decomposition of the test items of the second level, that is, they are subtasks of the previous test items. When solving tasks of the third level, the student proceeds to the second test item of the first level of complexity and then to the subsequent test items. With the wrong decision of the test items of the second level of complexity, the student beginning to study of e-textbooks. It is important that after going through the entire list of test items of varying complexity, the student is formed an idea of the most significant aspects of the topic under study, which allows him to quickly navigate in the educational materials.

The interaction with the program under test has traditionally been reduced to various ways of information exchange between the system and the user, as well as with other interfaces. In intelligent systems, the user's response affects not only the type of the next question, but also the database itself. Therefore, the local control system of the testing program should have an additional analytical subsystem. This gives you the ability to create adaptive tests that are self-correcting by levels of complexity, and then stored in the database for use in the assessment of knowledge.

Intermediate monitoring and assessment of the knowledge level is carried out after studying two or three learning topics. Depending on the number of studied topics, the student is presented with two or three blocks of tests, each of which contains three or four test items of the first level of complexity (Figure 2). As well as with the current knowledge monitoring, decomposition of test items at lower levels of complexity is performed. The possibility of moving to the next test item is not limited, and to the previous test item is prohibited. At the stage of intermediate monitoring, not only the total time of the tests, but also the trajectory of the test is considered. The results of two types of monitoring based on methods of mathematical statistics are compared and the assessment of the learning process is given, gaps in learning are identified, etc. $[4,5]$.

The information on the progress of the current and intermediate monitoring of student knowledge comes to the ALS analytical unit, where the calculations of three assessments of knowledge: current, intermediate and comprehensive. The final assessment of the student's knowledge is the comprehensive assessment. All three assessments are recorded in the ALS database with subsequent analysis of the effectiveness of the interactive learning process. Also, in the database are recorded new answers from the number of incomplete and partially correct answers to test items.

The implementation of the proposed algorithm for monitoring and assessment of knowledge based on ALS is possible with the help of special and universal software and does not require special knowledge of teachers to develop tests and procedures for assessing students' knowledge. For example, the implementation of ALS is possible on the base of LMS Moodle (Modular ObjectOriented Dynamic Learning Environment), which is freely available on the Internet [7].

The use of special and universal software products for the knowledge assessment of students in higher education can be possible only with a license and a quality certificate [8, 9]. Excel software products are developed in such a way as to enable an academic teacher to independently create text, graphical and multimedia test items and a procedure for monitoring and assessment of knowledge without special programming knowledge. Excel software also allows you to implement interactive adaptive learning of students with monitoring and knowledge assessment.

\section{Conclusion}

The results of the research have shown that the proposed comprehensive monitoring and assessment of student knowledge can improve the effectiveness of interactive learning by focusing students ' attention on the most important aspects of the learning materials, consistent submission of logically related test items, the ability to recognize incomplete and partially correct answers, the possibility of constant updating of the database of test items. The proposed 
interactive monitoring and evaluation of student knowledge can also be used in distance and e-learning.

Literature:

1. Brusilovsky, P., Christoph, P., Adaptive and Intelligent Webbased Educational Systems, International Journal of Artificial Intelligence in Education. (IJAIED), 2003, 13 (2-4), 159-172.

2. Brusilovsky. P., Sosnovsky S., Engaging students to work with self-assessment questions: a study of two approaches, ACM SIGCSE Bulletin 37/3, 2005: 251-255.

3. Dzhuguryan, L., Dzhuguryan, T., System kształcenia i monitoringu wiedzy w Polsce, Materials the 21st International Scientific and Methodological Conference „Education Quality Management of Specialists", Odessa State Academy of Civil Engineering and Architecture, (Ukraine), Part. 1, 2016, 5-6.

4. Dzhuguryan L.O., Оцінка ефективності процесу засвоєння знань при самостійній роботі студентів з використанням адаптивних навчально-контролюючих систем, Announcer of Odessa State Academy of Civil Engineering and Architecture, (Ukraine), 38, 2010, 218 - 222, (ukr).

5. Dzhuguryan T.G., Tonkonogy V.M., Dzhuguryan L.A., Автоматизированная адаптивная система обучения и контроля знаний, High-technologies in the Mechanical Engineering, Scientific Proceedings of National Technical University of Kharkov Polytechnic Institute, (Ukraine), 1(12), 2006, 141150, (ros).

6. Eggen, T.J.H.M., Straetmans, G.J.J.M., Computerized adaptive testing for classifying examinees into three categories. Educational and Psychological Measurement. 60, 2000: 713-734.

7. Horvat, Ana; Dobrota, M.; Krsmanovic, M.; \& Cudanov, M. Student perception of Moodle learning management system: a satisfaction and significance analysis, Interactive Learning Environments. 23 (4), 2015: 515-527.

8. Jelonek D., Chluski A., Rola agentów programowych w nauczaniu na odległość (The role of software agents in distance education), "Business Informatics", 17(118), 2010, 89-92.

9. Jelonek D., Dunay A., Illes B.C., Academic E-Learning Management with E-Learning Scorecard. Polish journal of management studies, Vol.16, No 2, 2017, 122-130.

10. Klaučo R., Várkoly L., Multimedia and teaching efficiency. [w:] Kiełtyka L. (Ed.): IT Tools in Management and Education. Selected Problems, The Publishing Office of Czestochowa University of Technology, Częstochowa 2011, 125-131.

11. Kolesnikova K.V., Tonkonogy V.M., Yakovenko O.Ye., Dzhuguryan L.O., Визначення достатнього числа питань в тестах при автоматизованому контролі знань, Proceeding of Odessa
Polytechnic University (Odessa, Ukraine), 2005, Special Vol., 812, (ukr).

12. Kolomiec L.V., Dzhuguryan L.O., Комплексна модульна оцінка знань 3 використанням адаптивних навчальноконтролюючих систем, Bulletin of Engineering Academy of Ukraine, Issue 1, 2010, 72-76, (ukr).

13. PN-EN ISO 9000:2015-10, Systemy zarządzania jakościa Podstawy i terminologia, Polski Komitet Normalizacyjny, Warszawa 2015, s. 26; PN-EN ISO 9001:2015-10, Systemy zarzadzania jakością - Wymagania, Polski Komitet Normalizacyjny, Warszawa 2015.

14. Sosnovsky S., Brusilovsky P., Evaluation of topic-based adaptation and student modeling in QuizGuide, User Modeling and User-Adapted Interaction 25/4, 2015: 371-424.

15. Trajer J., Paszek A., Iwan S., Zarządzanie wiedzą, Polskie Wydawnictwo Ekonomiczne, Warszawa, 2012.

16. Tertyshnaya T.I., Kolesnikova E.V., Gogunsky V.D., Automated control system of knowledge, Pratsi Odes. polytehn. University, (Odessa, Ukraine), 1(13), 2001, 125-128, (ros).

17. Tonkonogy V.M., Dzhuguryan L.O., Kolesnikova K.V., Автоматизированная интеллектуальная система обучения и контроля знаний практического материала графических дисциплин, High-technologies in the Mechanical Engineering, Scientific Proceedings of National Technical University of Kharkov Polytechnic Institute, (Kharkov, Ukraine), 1(13), 2007, 114123, (ros).

\section{Interaktywny monitoring i ocena wiedzy w oparciu 0 adaptacyjny system nauczania}

W artykule omówiono problemy, wady i zalety stosowania adaptacyjnych systemów nauczenia $w$ interaktywnym monitorowaniu i ocenie wiedzy. Określono metodyczne i techniczne aspekty interaktywnego monitorowania i oceny wiedzy w oparciu o adaptacyjny system nauczenia. Zaproponowano schematy algorytmów, na podstawie których realizowany jest proces nauczenia z jednoczesnym interaktywnym monitorowaniem i oceną wiedzy. Proponuje się zalecenia dotyczące wykorzystania oprogramowania do wdrażania interaktywnego monitorowania i oceny wiedzy w oparciu o adaptacyjnej systemie nauczenia.

Słowa kluczowe: system informatyczny, monitoring interaktywny, ocena wiedzy, nauczanie adaptacyjne, zarządzanie.

Autorka:

mgr inż. Lyudmyla Dzhuguryan - Szczecin, e-mail: I.dzhuguryan@gmail.com 